\title{
Poroqueratose Múltipla Digitada Pós-Irradiação: Caso Clínico
}

\author{
Rui Tavares Bello'; Pedro Ponte' ; Esmeralda Vale² \\ 'Dermatology Unit, Hospital dos Lusíadas, Lisbon, Portugal \\ ${ }^{2}$ Dermatopathology, Private Practice, Lisbon, Portugal
}

RESUMO - Um espectro de dermatoses de natureza variada - inflamatória, pré-neoplásica ou neoplásica - foi relatado como sequelas tardias de terapia de radiação. A poroqueratose múltipla digitada pós-irradiação (PMDPI), embora raramente reportada, emergiu como uma variante distinta entre as poroqueratoses. É relatado um caso de doente Caucasiana, de 47 anos de idade, que desenvolveu múltiplas pápulas filiformes, espiculadas, sobretudo na área peitoral direita, 12 meses após ter sido submetida a cobaltoterapia por carcinoma ductal infiltrativo da mama direita. As lesões, maioritariamente confinadas ao campo irradiado, evidenciavam ao exame histopatológico lamelas córneas sobre uma epiderme algo atrófica, privada de camada granulosa. A PMDPI é um subtipo peculiar, raro, de padrão de reacção cutânea poroqueratósica que suscita ponderação diagnóstica diferencial histopatológica com variadas dermatoses afins, incluídas no grupo heterogéneo das hiperqueratoses múltiplas digitadas. O caso é iconograficamente ilustrado e a literatura relevante é discutida.

PALAVRAS-CHAVE - Carcinoma Ductal da Mama/radioterapia; Queratoses; Poroqueratose/etiologia; Radioisótopos de Cobalto/efeitos adversos; Radioterapia/efeitos adversos.

\section{Postirradiation Multiple Minute Digitate Porokeratosis: Case Report}

ABSTRACT - A spectrum of skin conditions - inflammatory, preneoplastic and neoplastic in nature - have been reported to occur as late side effects of radiation therapy. Postiradiation multiple minute digitate porokeratosis (PIMMDP), although seldom reported, has emerged as a distinctively unique variant among porokeratoses. The case of a 47-year-old Caucasianwoman who developed multiple filiform spiny papules mainly over the right chest wall, 12 months after receiving post-operative cobalt therapy for infiltrating ductal carcinoma of the right breast, is reported. The papules, mostly confined to the irradiation field, were pathologically found to consist of cornoid lamellae overlying a somewhat atrophic epidermis devoid of granular layer. PIMMDP is a rare, peculiar type of a late-onset radiation-induced porokeratotic skin reaction pattern that should be differentiated on pathological grounds from other clinical mimickers such as those included in the heterogenous group of multiple minute digitate hyperkeratoses. This case is ichnographically depicted and the relevant literature is discussed.

KEYWORDS - Carcinoma, Ductal, Breast/radiotherapy; Cobalt Radioisotopes/adverse effects; Keratosis; Porokeratosis/etiology; Radiotherapy/adverse effects.

\section{INTRODUCTION}

The digitate keratoses are a heterogenous group of skin conditions characterized clinically by subtle, hardly visible, multiple, filiform, keratotic spicules that convey the skin a rough tactile feeling. Pathologically, either orthokeratotic or parakeratotic columns emerge from a diversely affected epidermis, either in relation with skin adnexae or not. However, the uniformity and uniqueness of the clinical features overshadow the fact that a number of distinct pathogenic events, triggers and entities have been reported to present in such
Correspondência: Rui Tavares Bello

Dermatology Unit, Hospital dos Lusíadas,

Lisbon, Portugal

Email: dermoclinica@netcabo.pt
Recebido/Received

16 Janeiro/January 2017

Aceite/Accepted

23 Fevereiro/February 2017 


\section{Caso Clínico}

Table 1 - Dermatoses presenting as digitate keratosis

\begin{tabular}{l}
\hline Multiple minute digitate hyperkeratosis $(\mathrm{MMDH})$ \\
\hline - Lichen spinulosus \\
\hline - Spiny keratoderma \\
\hline - Arsenical keratosis \\
\hline - Multiple filiform verrucae \\
\hline Postirradiation digitate (poro)keratosis \\
\hline - Trychodysplasia spinulosa \\
\hline Hyperkeratotic spicules \\
\hline
\end{tabular}

a manner. In fact, both inherited and acquired, inflammatory, metabolic, infectious and neoplastic conditions have been reported in this setting (Table 1), clearly justifying the need for a comprehensive diagnostic algorithm. ${ }^{1-3}$ An identical skin reaction pattern has also rarely been described as a late event after irradiation of breast carcinoma. Nonfollicular in character and mostly confined to the irradiated areas, postirradiation multiple minute digitate porokeratosis (PIMMDP) has emerged as a distinctively unique variant among the porokeratoses. ${ }^{4-6}$

\section{CASE REPORT}

A 47-year-old Caucasian female was evaluated for multiple asymptomatic tiny keratotic papules scattered over the skin of her right chest wall, axilla, neck and supraclavicular areas (Figs. 1 and 2). Lesions were mostly confined to the field of previous adjuvant radiotherapy, after a modified radical mastectomy procedure she endured, five years previously, for an infiltrating ductal carcinoma of the right breast. The patient had neither keratosis pilaris elsewhere nor a personal history of a localized or disseminated inflammatory skin disorder preceding her present condition. The spiny, 0.4-0.5

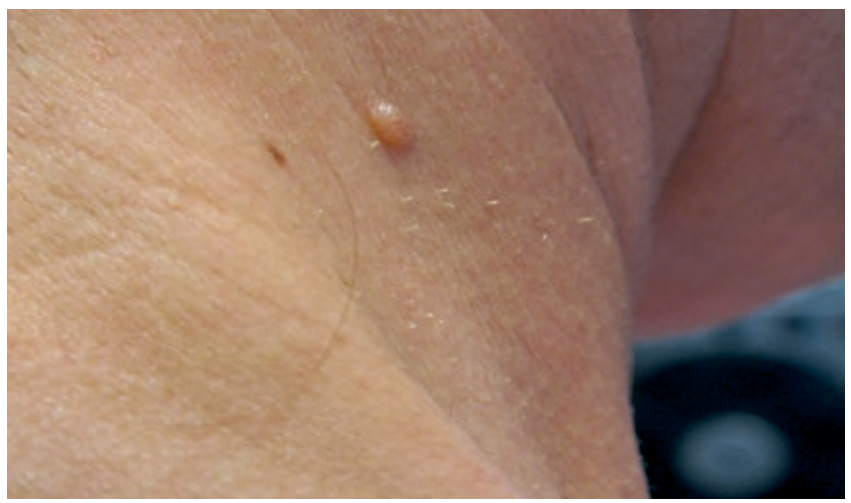

Figure 1 - Right cervical area.

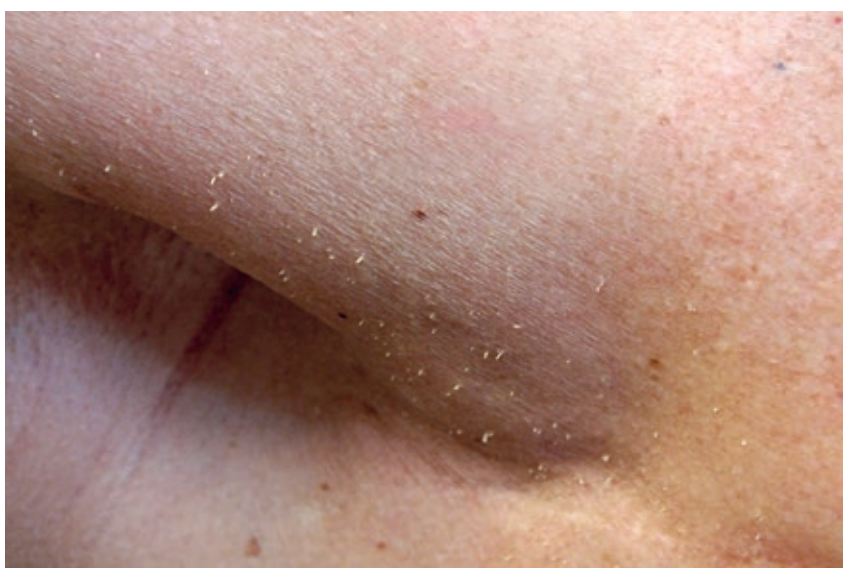

Figure 2 - Right pre-axillary area

$\mathrm{mm}$ diameter spicular papules, were firmly attached to a normal appearing skin and had resisted multiple topical treatments, mostly emollients and mild keratolytic agents. They started to appear 12 months upon completion of the radiotherapy program and had been stable for the last 4 years.

The patient was otherwise well, under no medications and had not suffered of any previous or concomitant skin disorder or ailment. There were no other abnormal physical signs and laboratory investigation including full blood count, electrolytes, liver and thyroid function tests, serum IgG, $A$ and $M$ levels, chest radiography and abdominal ultrasound, were unremarkable. A skin biopsy was performed (Figs. 3 and 4), that allowed to establish the diagnosis of porokeratosis. A 12\% ammonium lactate in an optimized lipid mixture lotion was prescribed; compliance was reportedly poor and results were hardly, if at all effective. Follow-up until recently (4 years after first observation, 9 after breast carcinoma therapy) testified the complete remission of the neoplasm and no further alterations in her general status; her skin condition was however still present and stable as compared with the one at presentation.

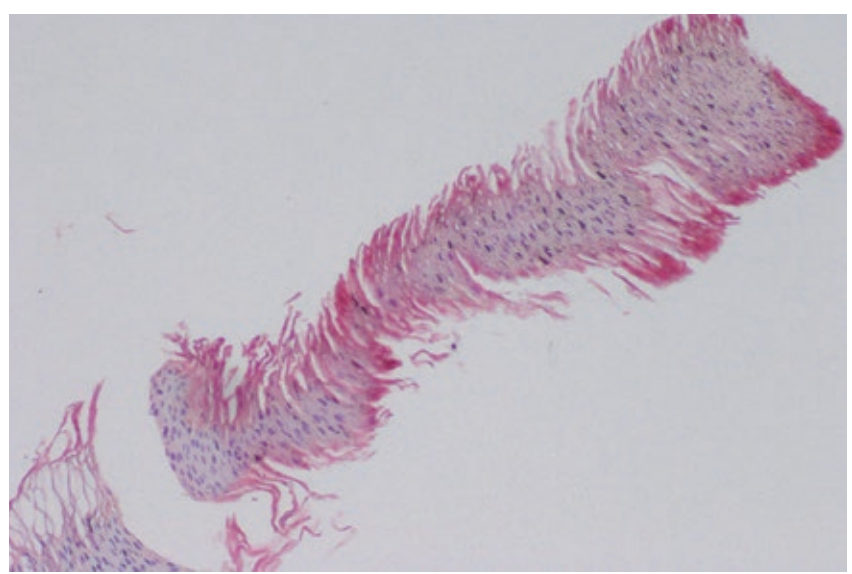

Figure 3 - Artifactually detached cornoid lamella. 


\section{Caso Clínico}

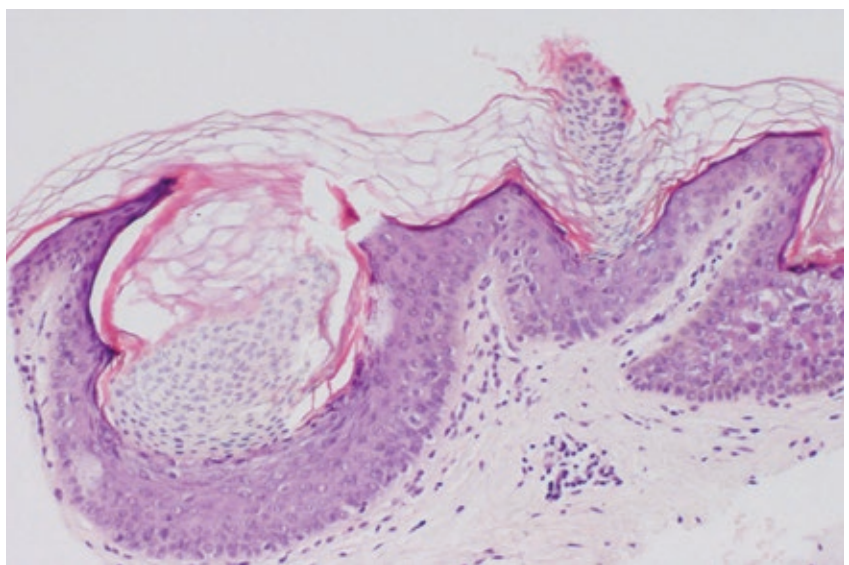

Figure 4 - Invaginated cup-shaped agranular epidermis and adjacent small cornoid lamella.

\section{DISCUSSION}

Digitate keratoses include both inherited and acquired skin disorders that encompass multiple minute digitate hyperkeratoses, lichen spinulosus, phrynoderma, spiny keratoderma, arsenical keratoses, trychodysplasia spinulosa and hyperkeratotic spicules, among others. ${ }^{3}$

Hyperkeratotic digitate keratotic papular projections the defining clinical hallmark of these conditions - have also been reported in porokeratosis palmaris plantaris and disseminata and, incidentally, in disseminated superficial actinic porokeratosis (DSAP) lesions, in patients under systemic retinoids or subjected to body-irradiation. ${ }^{7-9}$

Postirradiation multiple minute digitate porokeratosis (PIMMDP) is a rare, peculiar type of late-onset radiation-induced porokeratotic skin reaction pattern that should, on clinical and pathological grounds, be differentiated both from other chronic, late, skin radiation complications and other types of digitate keratoses. It is a very rarely reported nonfollicular digitate keratosis that is mostly confined to the irradiation field area and that had its onset within months to years after irradiation of breast cancer, primarily. $4,5,10$ It is ultimately the histological picture of focal columns of porokeratotic hyperkeratosis overlying an indented, somewhat atrophic epidermis, in the appropriate clinical setting, that allows to firmly establish the diagnosis of PIMMDP. Such was our patient's case: she bore no other lesions of porokeratosis elsewhere, her dermatosis was mostly circumscribed to the irradiated sites, had appeared 12 months upon completion of breast carcinoma therapy and had since persisted. Concerning therapy, the option for a $12 \%$ ammonium lactate lotion was empirical given the absence of therapeutic considerations in the reported cases of PIMMDP 3 ; patient's noncompliance first and, later on, her unwillingness to correct her condition do not, unfortunately, contribute to better clarify this issue.

Porokeratoses are a heterogenous group of inherited or acquired keratinization disorders, clinically characterized by papules or plaques with a distinct keratotic ridge with a central groove ("chemin de ronde") and, pathologically, by the presence of a focal column of parakeratotic hyperkeratosis ("cornoid lamellae"), over an atrophic, disorganized invaginated epidermis, devoid of granular layer. Several clinical presentations are well established, including the Mibelli, disseminated superficial actinic, linear, palmaris plantaris et disseminata variants, among others. Pathogenesis is not yet fully understood, but it has been postulated to arise from focal clonal keratinocyte mutations that are induced/triggered by stimuli such as ultraviolet (UV) exposure, electron beam radiation or immunosuppression. $8,11-14$ This is in line with our patient's case: The dermatosis was basically confined to the irradiated field and had its appearance after completion of radiation therapy. Although cornoid lamellation seems to represent a general disordered cornification histological reaction pattern - as it has been seen in varied inflammatory, hyperplastic and neoplastic dermatoses ${ }^{15}$ - it is nevertheless the findings on histologic sections that allowed to ascribe our patient's condition to the porokeratoses group and further pinpoint it specifically as PIMNDP.

A final comment on the evaluation of this seldom reported dermatosis: Having in mind the varied disorders that may present with minute digitate keratoses, it is mandatory to stress the usefulness of the comprehensive diagnostic algorithm put forward by Cacceta et al. ${ }^{3}$ It does prompt for a structured clinical approach that takes into account lesional distribution (localized versus disseminated), specific macro (palmar, facial...) or micro topography (follicular, nonfollicular eccrine-based lesions) diseased versus intact skin...

Conflitos de interesse: Os autores declaram não possuir conflitos de interesse.

Suporte financeiro: $O$ presente trabalho não foi suportado por nenhum subsídio ou bolsa.

Confidencialidade dos dados: Os autores declaram ter seguido os protocolos do seu centro de trabalho acerca da publicação dos dados de doentes.

Protecção de pessoas e animais: Os autores declaram que os procedimentos seguidos estavam de acordo com os regulamentos estabelecidos pelos responsáveis da Comissão de Investigação Clínica e Ética e de acordo com a Declaração de Helsínquia da Associação Médica Mundial

Conflicts of interest: The authors have no conflicts of interest to declare.

Financing Support: This work has not received any contribution, grant or scholarship.

Confidentiality of data: The authors declare that they have followed the protocols of their work center on the publication of data from patients.

Protection of human and animal subjects: The authors declare that the procedures followed were in accordance with the regulations of the relevant clinical research ethics committee and with those of the Code of Ethics of the World Medical Association (Declaration of Helsinki). 


\section{Caso Clínico}

\section{REFERENCES}

1. Goldstein N. Multiple minute digitate keratoses. Arch Dermatol. 1967; 96:692-3.

2. Benoldi D, Zucchi A, Allegra. Multiple minute digitate keratoses. Clin Exp Dermatol. 1993; 18: 261-2.

3. Caccetta TP, Dessauvage B, McCallum D, Kumarasinghe SP. Multiple minute digitate hyperkeratoses: a proposed algorithm for the digitate keratoses. J Am Acad Dermatol., 2012; 67:e49-55.

4. Burns DA. Postirradiation minute digitate hyperkeratosis. Clin Exp Dermatol. 1986;1 1:646-9.

5. Vestey JP, Hunter JAA. Post-irradiation digitate keratoses. Clin Exp Dermatol. 1987; 12:315-6.

6. Pujol RM, Perez-Losada E, Matias-Guiu X, Fuentes J, Alonso $C$, et al. Postirradiation multiple minute digitate porokeratosis. J Cut Med Surg. 2001; 2:126-30.

7. Carmichael AJ, Tan Y. Digitate keratoses - a complication of etretinate used in the treatment of disseminated superficial actinic porokeratoses. Clin Exp Dermatol. 1990; 15:370-1.

8. Romani J, Pujol RM, Casanova JM, De Moragas JM. Disseminated superficial porokeratoses developing after electron-beam total skin irradiation for mycosis fungoides. Clin Exp Dermatol. 1996; 21:310-2.

9. Goldschmidt H, Sherwin WK. Reactions to ionizing radiation. J Am Acad Dermatol. 1980; 2:551-79.

10. Mizuno K, Okamoto H, Imamura S. POstirradiation multiple minute digitate hyperkeratoses. Clin Exp Dermatol. 1995; 20:425-7.

11. Happle R. Cancer proneness of linear porokeratosis may be explained by allelic loss. Dermatology. 1997; 195:20-5.

12. Ibbotson SH. Disseminated superficial porokeratosis: what is the association with ultraviolet radiation? Clin Exp Dermatol. 1996; $21: 48-50$.

13. Halper S, Medinica M. Porokeratosis in a patient treated with total body electron beam radiation. J Am Acad Dermatol. 1990; 23:754-5.

14. James AJ, Clarke LE, Elenitsas R, Katz K. Segmental porokeratosis after radiation therapy for folicular lymphoma. J Am Acad Dermatol. 2008; 58(Suppl):S49-S50.

15. Wade TR, Ackerman AB. Cornoid lamellation: a histologic reaction pattern. Am J Dermatopathol. 1980; 2:515. 